\title{
Evaluation of nutritional, biological and microbiological properties of jam sweetened by date "debs"
}

\author{
Hanan M. El-Ghandour, Ahmed F. Abdel-Salam and Ghadir A. El-Chaghaby \\ Regional Center for Food and Feed, Agricultural Research Center, Giza, EGYPT
}

\begin{abstract}
One of the important products of date palms is date syrup. Date syrup locally known as "debs" is probably the most common derived date product. The present work was done to evaluate the antioxidant capacity as well as the biological effects of date syrup locally known as "debs" on streptozotocin-induced diabetic rats and to investigate the microbiological changes occurring during the storage of jam containing debs replacing sucrose. The results of phytochemical screening showed that "debs" contains different constituents such as flavonoids, phenols, steroids, and saponins that could be effective as antioxidant and antimicrobial substances. The results also revealed that "debs" has high antioxidant capacity. For the biological study thirty six healthy adult Albino male rats were used. The data collected for blood glucose levels indicated the antidiabetic effect of debs. The results of the microbiological study revealed that the addition of date debs instead of sucrose resulted in the decrease of microbial load in jam upon storage up to three months.
\end{abstract}

Keywords: dates; debs; diabetes; streptozotocin; phytochemical; antioxidant; antibacterial

\section{Introduction}

Date palm (Phoenix dactyliferaL.) has been cultivated since thousands of years in Egypt. According to the Food and Agriculture Organization, there are 14 million palm trees, occupying 30,934 ha, which represents

$6.32 \%$ of the fruit cultivated area in Egypt representing about $20 \%$ of the total world production (Al-Khayri et al., 2015). Date fruits are good sources of many important elements such as $\mathrm{K}, \mathrm{Na}, \mathrm{Ca}, \mathrm{Mg}, \mathrm{Fe}$ and $\mathrm{Zn}$ as well as source of amino acids and vitamins A, B1 and B2 (Wafaa et al., 2016).

One of the important products of date palms is date syrup. Date syrup locally known as "debs" is probably the most common derived date product (Al-Khayri et al., 2015). It is a natural extract of dates, without any additives, colors or preservatives (Doma et al., 2016). Date syrup contains various components such as carbohydrates, proteins, lipids, pectin, salts and minerals (Gabsi et al., 2013).The date syrup is directly consumed or used as an ingredient in some food formulation such as ice cream products, beverage, confectionery, bakery products, sesame paste/date syrup blends, jam and butter (Abbès et al., 2013).Date syrup is a rich source of phenolic compounds which are known potent radical scavengers, and also it has antibacterial activity attributed to its bioactive components including plant-derived phenolic molecules (Taleb et al.,2016).

Diabetes mellitus (DM) is rapidly spreading disease worldwide; it is associated with long-term complications especially with increased oxidative stress that results in alteration of several cellular biomolecules (Hasan and Mohieldein, 2016). It has been demonstrated that, reactive oxygen species (ROS) could play a key event in the development of diabetes complications such as hepatic injury (Hussein et al., 2015). 


\section{Hanan M. El-Ghandour et al.,}

Over the years, many conventional medicines were used to control diabetes. Natural products are a good remedy as they are inexpensive and easy to access without any complications. Dates and their constituents show a role in diseases prevention through anti-oxidant, anti-inflammatory, anti-bacterial activity (Rahmani et al., 2014). Some studies have proven that date palm extracts have a hypoglycaemic effect in alloxan-induced diabetic rats and were highly effective in managing the complications of diabetes mellitus such as hyperlipidemia and weight loss (Mard et al.,2010).

In the present study, the objectives of the work are to evaluate the antioxidant capacity as well as the biological effects of date syrup on streptozotocin-induced diabetic rats and microbiological changes occurring during the storage of jam containing date syrup instead of sucrose.

\section{Materials and Methods}

Date syrup was purchased from local supermarket in Egypt. Two types of treatments were done to the date syrup, in the first treatment date syrup was dried completely (syrup A) and in the second treatment it was semi dried (syrup B).

\section{Preparation of jam}

Jam preparation was done as described by Habiba and Mehaia, (2007) with some modifications. To prepare the jam samples, apples purchased from local market, washed, peeled and cut into cubes. The cubes were then cooked in stainless steel container. The apple cubes were mixed with sugar in ratio $45 \%$ to $55 \%$, gently heated and when the total soluble solids (TSS) reached $65 \%$, pectin was added $(5 \mathrm{~g} / \mathrm{kg}$ of apple: sugar mixture) followed by the addition of citric acid ( $3 \mathrm{~g} / \mathrm{kg}$ of added sugar). Finally, the resultant jam was hot filled in clean dry jars. Jam pH was 4. The cooked fruit was mixed with "date debs" dried or semi dried instead of sugar and a control jam was made by adding sugar. The cooking of the jam was continued and then jam samples were cooled and placed in glass jars.

\section{NUTRITIONALEVALUATION}

\section{1- INVITRO:}

\section{TOTAL ANTIOXIDANT ACTIVITY (TAA)}

The total antioxidant activity of syrups $A$ and $B$ was determined using the phosphomolybdenum method according to the procedure described by Prieto et al., (1999). The antioxidant activity was calculated using a standard curve of ascorbic acid.

\section{TOTAL PHENOLIC CONTENTS (TPC)}

Contents of total phenolics of the syrups were estimated by spectrophotometer using the FolinCiocalteu assay (Singleton et al., 1999). A standard curve was plotted using different concentrations of Gallic acid. The absorbance obtained was converted to gallic acid equivalent in $\mathrm{mg}$ per gm of dry material [mg GAE/g] using gallic acid standard curve.

\section{TOTAL FLAVONOIDS (TF)}

Total flavonoids content was determined as described by the method of Willet (2002). Total flavonoids content results were reported as equivalents to querectin used as standard.

\section{PHYTOCHEMICAL SCREENING}

Date syrup samples were tested for the presence of different classes of secondary metabolites using previously described methods of Harbone, (1973). 


\section{Egypt. J. of Nutrition and Health Vol. 14 No. 1 January (2019)}

\section{2- IN VIVO BIOLOGICAL EVALUATION}

A total number of 36 healthy adult Albino male rats between 2 and 3 months of age and weighing about 180-200 $\mathrm{g}$ were used for the study. The rats were housed in cages with 12/12 hrs light/dark cycles at 22$23^{\circ} \mathrm{C}$. The rats were maintained in this condition for a period of three days to acclimatize them prior to experimental uses. The animals were fed with standard rat diet AIN-76 and water ad libitum according to NRC, (1995).

\section{INDUCTION OF DIABETES MELLITUS}

Diabetes was induced in overnight fasted adult Albino male rats weighing $180-200 \mathrm{~g}$ by a single intraperitoneal injection of $50 \mathrm{mg} / \mathrm{kg}$ body weight streptozotocin (Sigma Aldrich, Germany) in $0.1 \mathrm{M}$ citrate buffer of $\mathrm{pH}$ 4.4. Hyperglycemia was confirmed by the elevated glucose levels in plasma, determined at $72 \mathrm{~h}$ and then on day 7 after injection.

\section{EXPERIMENTAL DESIGN}

Total 36 rats were included and were divided into 6 groups, each groups consist of six rats as follows: 6 rats on basal diet and left as negative control and the rest were diabetic.

Group I: Normal control (control -)

Group II:Diabetic control (control +streptozotocin)

Group III:Diabetic with syrup A (5\%)

Group IV:Diabetic with syrup A (10\%)

Group V: Diabetic with syrup B (5\%)

Group VI: Diabetic with syrup B (10\%)

\section{BLOOD SAMPLING}

Blood samples for glucose analysis were taken after overnight fasting from orbital flexus nervous by using fine capillary tube. Blood samples were obtained at 0,4,6,8 and 10 weeks and were tested using blood glucose meter (Merck Microlab 200).

\section{BACTERIOLOGICAL EXAMINATIONS}

Jam samples were stored for three months and bacteriological tests were carried out at different storage intervals. Total bacterial count was carried out according to Berrang et al., (2001). Faecal coliform counts were carried out according to Mercuri and Cox (1997). Total yeasts and molds were carried out according to NMKL (1999).

Isolation of E.coli was carried out according to Collins et al., (1998). E.coli colonies are green metallic sheen on Eosin methylene blue (EMB) agar medium. E. coli identification attempts were made using the criteria described by Kreig and Holt (1984) using the following tests: growth on TSI, urea, indole, M.R, V. P and sugar fermentation.

Isolation of Staphylococcus aureus was carried out according to Gouda (2000). The isolation of Staphylococcus aureus is based on the appearance of black, convex, shiny colonies surrounded by a yellow zone on Vojel Johnson agar medium.Isolation of Clostridium perfringens was carried out according to FAO (1992),..Cl. Perfringens colonies are black on clostridium perfringens selective agar base supplemented with tryptone- sulf-cycloserine (TSC) supplement.

\section{STATISTICAL ANALYSIS}

Statistical data was carried out with the use of Microsoft Excel 2010 computer program. Results are expressed as mean $\pm S D$. Comparisons between groups were made using Student's t-test and $p$ values $<0.05$ were considered as significant. 


\section{Results and Discussion}

\section{Phytochemical constituents of date syrup}

In the present study, the phytochemical screening of date syrup indicated the presence of different constituents such as flavonoids, phenols, steroids, and saponins (Table 1). The phytochemical screening confirmed the presence of various classes of biologically active plant metabolites that could be effective as antioxidant and antimicrobial substances. Phytochemical constituents are highly responsible for many protective health benefits. So based on the phytochemical screening results "debs" could offer many advantages for human health.

Table(1)

Phytochemicals of date syrups

\begin{tabular}{c|c|c|c|c|c|c|c}
\hline Sample & Tannins & Flavonoids & Saponins & Alkaloids & Steroids & Phenols & Terpenoids \\
\hline Syrup A & + & + & + & - & + & + & - \\
\hline Syrup B & + & + & + & - & + & + & - \\
\hline
\end{tabular}

Positive sign (+) indicates presence, negative sign (-) indicates absence

\section{Antioxidant properties of date dibs}

In the present study, the antioxidant properties of date syrups are presented in Table (2). The results show higher antioxidant capacity for Syrup B compared to Syrup A. Antioxidant activity is recognized due to the wide range of phenolic compounds present in dates including p-coumaric, ferulic, and sinapic acids, flavonoids, and procyanidins(Rahmani et al., 2014).

The total phenolic compounds as well as the total flavonoids were also found in elevated amounts in Syrup B compared to Syrup A. Antioxidants stabilize or deactivate free radicals, often before they attack targets in biological cells (Saeed et al., 2012). Phenolic compounds and flavonoids are powerful antioxidants and act in a structure-dependent manner; they can scavenge reactive oxygen species (ROS), and chelate transition metals which play vital roles in the initiation of deleterious free radical reactions (Wang et al.,2010).

Numerous in vitro studies have suggested that antioxidant potential and other useful biological actions of medicinal plants could be attributed to their high phenolic contents. The phenolic compounds by virtue of their reducing properties can absorb and neutralize free radicals, quench singlet and triplet oxygen, or decompose peroxides to act as antioxidant (Khan et al., 2016). Previous studies concerning the composition of date syrup have identified significant antioxidant capacity which may imply to the scientific basis of date fruit and date syrup's traditional medicinal application (Taleb et al.,2016).

Table (2)

Total antioxidant capacity, total phenols and flavonoids of date syrups

\begin{tabular}{c|c|c|c}
\hline Sample & $\begin{array}{c}\text { Total antioxidant capacity } \\
(\mathrm{mg} / 100 \mathrm{~g} \text { ascorbic acid equivalent })\end{array}$ & $\begin{array}{c}\text { Total phenolic content } \\
(\mathrm{mg} / 100 \mathrm{~g} \text { gallic acid equivalent })\end{array}$ & $\begin{array}{c}\text { Total flavonoids }(\mathrm{mg} / 100 \mathrm{~g} \\
\text { querectin acid equivalent) }\end{array}$ \\
\hline Syrup A & 122.43 & 582.95 & 15.60 \\
\hline Syrup B & 141.59 & 1205.15 & 23.05 \\
\hline
\end{tabular}




\section{Egypt. J. of Nutrition and Health Vol. 14 No. 1 January (2019)}

\section{Effect of date syrup on blood glucose of diabetic rats}

The results showing the effect of replacing sucrose with date syrup on blood glucose of diabetic rats are given in Table (3). There were no significant differences $(p>0.05)$ between all groups at the start of the experiment as all groups were normal rats taking same diet. After 4 weeks, Group I recorded significantly $(p<0.05)$ lower blood glucose compared to all other groups injected with streptozotocin. It is known that streptozotocin (STZ) is used as an agent to induce diabetes mellitucreatic injury and by pan selective cytotoxicity effect on pancreatic beta cells which leads to an increase in blood glucose level (Shirwaikar et al., 2004; .Hasan and Mohieldein, 2016).

During the experimental period from week 6 to the end of experiment (week 10), it was observed that the groups (III, IV, V and VI) consuming date syrup showed significantly $(p<0.05)$ lower blood glucose levels as compared to the positive control group II, nevertheless the glucose level of these groups was still significantly higher than that of the healthy controls (group I). This means that the consumption of date syrup decreased the blood glucose level of diabetic rats but did not completely treat diabetes as the rats did not retain their normal blood glucose levels. It is also worthy to note that the rats in group VI recorded the significantly $(p<0.05)$ lowest blood glucose value when compared to other treated groups and to the positive control group. This signifies that the semi dried date syrup at a level of $10 \%$ was the best treatment in the present work.

Previous studies conducted on diabetic rats showed that continuous administration of aqueous extract of Saudi date seed significantly reduced the blood glucose concentration in STZ induced diabetic rats for 8 weeks. Also, the hypoglycemic effect of date seed extract along with insulin treatment as well as the endogenous stimulation of Insulin production has been reported (Hasan and Mohieldein, 2016). The antidiabetic effect of date syrup could be due to the effect of active flavonoids, phenols, steroids, and saponins; these compounds may scavenge free radicals in diabetic rats. Hypoglycaemic effects have been reported for some plants that contain flavonoids (Rahmani et al., 2014).

Table (3)

Effect of dibs on blood glucose levels in experimental rats

\begin{tabular}{c|c|c|c|c|c}
\hline & $1^{\text {st }}$ week & 4 weeks & 6 weeks & 8 weeks & 10 weeks \\
\hline Group I & $107.50^{\mathrm{a}} \pm 12.99$ & $108.00^{\mathrm{e}} \pm 2.58$ & $101.50^{\dagger} \pm 1.98$ & $102.75^{\dagger} \pm 0.90$ & $108.75^{\dagger} \pm 2.37$ \\
\hline Group II & $113.33^{\mathrm{a}} \pm 3.54$ & $300.00^{\mathrm{a}} \pm 13.31$ & $305.00^{\mathrm{a}} \pm 12.97$ & $310.00^{\mathrm{a}} \pm 13.40$ & $310.00^{\mathrm{a}} \pm 14.34$ \\
\hline Group III & $115.00^{\mathrm{a}} \pm 3.84$ & $260.00^{\mathrm{b}} \pm 8.04$ & $230.00^{\mathrm{c}} \pm 5.98$ & $215.00^{\mathrm{c}} \pm 9.43$ & $200.00^{\mathrm{c}} \pm 5.00$ \\
\hline Group IV & $117.50^{\mathrm{a}} \pm 2.38$ & $260.00^{\mathrm{b}} \pm 6.36$ & $200.00^{\mathrm{d}} \pm 1.92$ & $170.00^{\mathrm{d}} \pm 11.70$ & $140.00^{\mathrm{d}} \pm 3.62$ \\
\hline Group V & $113.75^{\mathrm{a}} \pm 1.92$ & $250.00^{\mathrm{c}} \pm 1.87$ & $250.00^{\mathrm{b}} \pm 4.39$ & $235.00^{\mathrm{b}} \pm 6.58$ & $224.00^{\mathrm{b}} \pm 8.08$ \\
\hline Group VI & $106.00^{\mathrm{a}} \pm 1.63$ & $230.00^{\mathrm{d}} \pm 6.30$ & $180.00^{\mathrm{e}} \pm 0.79$ & $160.00^{\mathrm{e}} \pm 7.32$ & $133.00^{\mathrm{e}} \pm 0.61$
\end{tabular}

a,b,c......f: different superscripts within the same column indicate significant differences $(p<0.05)$

\section{Microbiological study}

The effect of replacing sucrose by date syrup on the microbiological and properties of this jam was evaluated through storage. In this respect the total bacterial count (TBC), faecal coliform (FC), and total fungi (TF) were measured in jam samples containing sucrose, syrup A or syrup B at different preservation time (zero, one month, two months and three months). The microbiological results are shown in Tables (4 7). It is observed that during every single storage period the total bacterial count and yeasts were significantly $(p<0.05)$ lower in the jam containing syrup B followed by that one containing syrup $A$ and the highest microbial count was found in the jam with sucrose.Also it was found that faecal coliform and total fungi were not present in any of the samples throughout storage period up to two months. 


\section{Hanan M. El-Ghandour et al.,}

After two months of storage (Table 6) there was a notable decrease in the total bacterial count of jam samples containing syrup $A$ and syrup $B$ and no coliform were detected. After three months of storage (Table 7), it was noticed that the total bacterial counts of syrup A and syrup B jams were significantly lower than that of sucrose jam.

Table ( 4 )

Microbiological analysis of jam made by sucrose and debs (semi and dry) at zero time

\begin{tabular}{c|c|c|c|c|c|c|c}
\hline \multirow{2}{*}{ Treatments } & \multicolumn{5}{|c|}{ Count } & \multicolumn{3}{c}{ Isolation } \\
\cline { 2 - 8 } & T.B.C & F.C & T.F & Yeasts & E.coli & Staph. aureus & Cl. perfringens \\
\hline Sucrose & $6 \times 10^{5 \mathrm{a}}$ & 0 & 0 & $2 \times 10^{5 \mathrm{a}}$ & 0 & 0 & 0 \\
\hline Syrup A & $5 \times 10^{4 \mathrm{~b}}$ & 0 & 0 & $6 \times 10^{3 \mathrm{~b}}$ & 0 & 0 & 0 \\
\hline Syrup B & $3 \times 10^{3 \mathrm{c}}$ & 0 & 0 & $2 \times 10^{3 \mathrm{~b}}$ & 0 & 0 & 0 \\
\hline
\end{tabular}

a,b,c: different superscripts within the same column indicate significant differences $(p<0.05)$ T.B.C: total bacterial count; T.C: total coliform; F.C: feacal coliform; T.F: total fungi

Table ( 5 )

Microbiological analysis of jam made by sucrose and debs (semi and dry) after one month of storage

\begin{tabular}{c|c|c|c|c|c|c|c}
\hline \multirow{2}{*}{ Treatments } & \multicolumn{4}{|c|}{ Count } & \multicolumn{3}{c}{ Isolation } \\
\cline { 2 - 7 } & T.B.C & F.C & T.F & Yeasts & E.coli & Staph. aureus & Cl. perfringens \\
\hline Sucrose & $6 \times 105 \mathrm{a}$ & 0 & 0 & $9 \times 105 \mathrm{a}$ & 0 & 0 & 0 \\
\hline Syrup A & $4 \times 103 \mathrm{~b}$ & 0 & 0 & $8 \times 103 \mathrm{~b}$ & 0 & 0 & 0 \\
\hline Syrup B & $2 \times 102 \mathrm{c}$ & 0 & 0 & $6 \times 103 \mathrm{~b}$ & 0 & 0 & 0 \\
\hline
\end{tabular}

a,b,c: different superscripts within the same column indicate significant differences $(p<0.05)$ T.B.C: total bacterial count; F.C: feacal coliform; T.F: total fungi

Table (6)

Microbiological analysis of jam made by sucrose and debs (semi and dry) after two months of storage

\begin{tabular}{c|c|c|c|c|c|c|c}
\hline \multirow{2}{*}{ Treatments } & \multicolumn{5}{|c|}{ Count } & \multicolumn{2}{c}{ Isolation } \\
\cline { 2 - 8 } & T.B.C & F.C & T.F & Yeasts & E.coli & Staph. aureus & Cl. perfringens \\
\hline Sucrose & $7 \times 104 \mathrm{a}$ & 0 & 0 & $3 \times 105 \mathrm{a}$ & 0 & 0 & 0 \\
\hline Syrup A & $4 \times 103 \mathrm{~b}$ & 0 & 0 & $4 \times 103 \mathrm{~b}$ & 0 & 0 & 0 \\
\hline Syrup B & $2 \times 102 \mathrm{c}$ & 0 & 0 & $7 \times 102 \mathrm{c}$ & 0 & 0 & 0 \\
\hline
\end{tabular}

$a, b, c$ : different superscripts within the same column indicate significant differences $(p<0.05)$ T.B.C: total bacterial count; F.C: feacal coliform; T.F: total fungi 
Egypt. J. of Nutrition and Health Vol. 14 No. 1 January (2019)

Table ( 7 )

Microbiological analysis of jam made by sucrose and debs (semi and dry) after three months of storage

\begin{tabular}{c|c|c|c|c|c|c|c}
\hline \multirow{2}{*}{ Treatments } & \multicolumn{5}{|c|}{ Count } & \multicolumn{3}{c}{ Isolation } \\
\cline { 2 - 8 } & T.B.C & F.C & T.F & Yeasts & E.coli & Staph. aureus & Cl. perfringens \\
\hline Sucrose & $8 \times 104 \mathrm{a}$ & 0 & 0 & $2 \times 106 \mathrm{a}$ & 0 & 0 & 0 \\
\hline Syrup A & $3 \times 103 \mathrm{~b}$ & 0 & 0 & $6 \times 105 \mathrm{~b}$ & 0 & 0 & 0 \\
\hline Syrup B & $2 \times 102 \mathrm{c}$ & 0 & 0 & $4 \times 104 \mathrm{c}$ & 0 & 0 & 0 \\
\hline
\end{tabular}

a,b,c: different superscripts within the same column indicate significant differences $(p<0.05)$ T.B.C: total bacterial count; F.C: feacal coliform; T.F: total fungi

The results of the microbiological study revealed that the addition of date syrup instead of sucrose resulted in the decrease of microbial load in jam upon storage up to three months of storage.The antimicrobial effect of date syrup could be attributed to its phenolic content. Previous work of Taleb et al. (2016) reported that date syrup polyphenols, the most abundant bioactive constituent in date syrup, have antibacterial activity.

\section{Conclusion}

Date syrup (debs) contains several bioactive components which makes it good antioxidant and antibacterial component in food. Debs consumption could be beneficial for maintaining blood glucose levels around normal levels. Further studies must be continued to investigate the effect of long term consumption of debs and its effect on diabetic rats.

\section{References}

Abbès, F., Kchaou, W., Blecker, C., Ongena, M., Lognay, G., Attia, H., and Besbes, S. (2013).

Effect of processing conditions on phenolic compounds and antioxidant properties of date syrup.Industrial Crops and Products, 44, 634-642.doi:10.1016/j.indcrop.2012.09.008

Al-Khayri, J. M., Jain, S. M., and Johnson, D. V. (2015).

Date palm genetic resources and utilization: Volume 1: Africa and the Americas. Date Palm Genetic Resources and Utilization: Volume 1: Africa and the Americas (Vol. 1). doi:10.1007/978-94-0179694-1

Berrang M. E., S. R. Ladely, And R. J. Buhr (2001)

Presence and Level of Campylobacter, Coliforms, Escherichia coli, and Total Aerobic Bacteria Recovered from Broiler Parts with and without Skin. Journal of Food Protection, Vol. 64, No. 2, pp. 184-188.

Collins, C. H., Lyne, P. M. and Grange, G. M. (1998).

Microbiological Methods.67th Ed. Butter woths.London.460-520 pp. 
Hanan M. El-Ghandour et al.,

Doma,M.B. ;,EL-Shahawy,S.M.M.,andGrawish,S.A.H.(2016).

Processing of date honey.J.Food and Dairy Sci., 4(3), 51-64.

FAO (1992).

Manual of Food Quality Control, Microbiological analysis.Food and Agriculture organization Rome, Italy.

Gabsi, K., Trigui, M., Barrington, S., Helal, A. N., and Taherian, A. R. (2013).

Evaluation of rheological properties of date syrup. Journal of Food Engineering, 117(1), 165-172. doi:10.1016/j.j food eng.2013.02.017

Gouda, H. (2000).

Microbiological studies on some fish aquaculture in Egypt, B.Sc. theses faculty of agriculture.Cairo University. pp. 52-69.

Habiba, R.A. \& Mehaia, M.A.E. (2007)

Improving Carrot Jam Characteristics and Its Nutritional Value by Using Date Paste Instead of Sugar.Journal of Agricultural and Veterinary Sciences, 1.

Harborne, J. B. (1973).

Phytochemical methods: A guide to modern techniques of plant analysis. Chapman and Hall Ltd, London.

Hasan, M., and Mohieldein, A. (2016).

In vivo evaluation of anti diabetic, hypolipidemic, antioxidative activities of saudi date seed extract on streptozotocin induced diabetic rats. Journal of Clinical and Diagnostic Research, 10(3), FF06FF12. doi:10.7860/JCDR/2016/16879.7419

Hussein, A. M., El-mousalamy, A. M. D., Hussein, S. A. M., and Mahmoud, S. A. (2015).

Effects of Palm Dates ( PhoenixDactylifera L ) Extracts on Hepatic Dysfunctions in Type 2 Diabetic Rat Model. World Journal of Pharmacy and Pharmaceutical Sciences, 4(07), 62-79.

Khan, S. A., Al Kiyumi, A. R., Al Sheidi, M. S., Al Khusaibi, T. S., Al Shehhi, N. M., and Alam, T. (2016). In vitro inhibitory effects on a-glucosidase and $\alpha$-amylase level and antioxidant potential of seeds of Phoenix dactylifera L. Asian Pacific Journal of Tropical Biomedicine, 6(4), 322-329. doi:10.1016/j.apjtb.2015.11.008

Krieg, N.R. and Holt, J.G. (1984)

Bergey's Manual of Systematic Bacteriology. Williams and Wilkins, Baltimore, London.

Mard, S. A., Jalalvand, K., Jafarinejad, M., Balochi, H., and Naseri, M. K. G. (2010).

Evaluation of the antidiabetic and antilipaemic activities of the hydroalcoholic extract of phoenix dactylifera palm leaves and its fractions in alloxan-induced diabetic rats. Malaysian Journal of Medical Sciences, 17(4), 4-13. 


\section{Egypt. J. of Nutrition and Health Vol. 14 No. 1 January (2019)}

MercuriA. J .and Cox N. A. (1979)

Coliforms and Enterobacteriaceae Isolates from Selected Foods. Journal of Food Protection: September 1979, Vol. 42, No.9, 712-714.

NMKL.Nordic Committee for Food Analysis.(1999)

Guide on quality assurance in microbiological laboratories. Report no. $98,3^{\text {rd }}$ edition.

Prieto P,Pineda M,Aguilar M .(1999)

Spectrophotometricquantitation of antioxidantcapacitythroughthe formationofa phosphomolybdenum complex: specific application to the determination of vitamin E. Anal Biochem 269:337-41.doi:10.1006/abio.1999.4019.

Rahmani, A. H., Aly, S. M., Ali, H., Babiker, A. Y., Suikar, S., and Khan, A. A. (2014).

Therapeutic effects of date fruits (Phoenix dactylifera) in the prevention of diseases via modulation of anti-inflammatory, anti- oxidant and anti-tumour activity. International Journal of Clinical and Experimental Medicine, 7(3), 483- 491.

Saeed, N., Khan, M. R., and Shabbir, M. (2012). Antioxidant activity, total phenolic and total flavonoid contents of whole plant extracts Torilis leptophylla L. BMC Complementary and Alternative Medicine, 12(1), 221. doi:10.1186/1472-6882$12-221$

Shirwaikar, A., Rajendran, K., Dinesh Kumar, C., and Bodla, R. (2004). Antidiabetic activity of aqueous leaf extract of Annona squamosa in streptozotocin-nicotinamide type 2 diabetic rats. Journal of ethnopharmacology, 91(1), 171-5. doi:10.1016/j.jep.2003.12.017

Singleton VL, Orthofer R, Lamuela-Raventós RM 1999. Oxidants and Antioxidants Part A. vol. 299. Elsevier; doi:10.1016/S0076-6879(99)99017-1.

Taleb, H., Maddocks, S. E., Morris, R. K., and Kanekanian, A. D. (2016).

The Antibacterial Activity of Date Syrup Polyphenols against $\mathrm{S}$. aureus and E. coli.Frontiers in microbiology, 7, 198. doi:10.3389/fmicb.2016.00198

Wafaa, M. S., Samiha, A. A., and Waheed, A. R. (2016).

Effect of substituting sucrose with date syrup concentrate on the quality of soy ice cream.Journal of American Science, 20(2), 221-233. doi:10.7537/marsjas12061601.Key

Wang, H., Gan, D., Zhang, X., and Pan, Y. (2010).

Antioxidant capacity of the extracts from pulp of Osmanthus fragrans and its components.LWT Food Science and Technology, 43(2), 319-325. doi:10.1016/j.lwt.2009.08.003

Willet, W.C. (2002).

Balancing life-style and genomics research for disease prevention. Sci. 296: 695-698. 


\section{Hanan M. El-Ghandour et al.,}

تقييم الخصائص التظذوية والبيولوجية والميكروبية للمربى المحلاه بدبس التمر

$$
\begin{aligned}
& \text { د. حنان محمالغندور د. أحمد فريدعبدالسلام رد. غديرعلي الشغبي } \\
& \text { المركز الإقليمي للأغذية والأعلاف ـ مركز البحوث الزر اعية }
\end{aligned}
$$

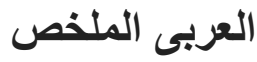

تم إجراء هذا البحث لتقييم القدرة المضادة للأكسدة وكذلك التأثير ات البيولوجية لثراب التمر المعروف محليا بإسم

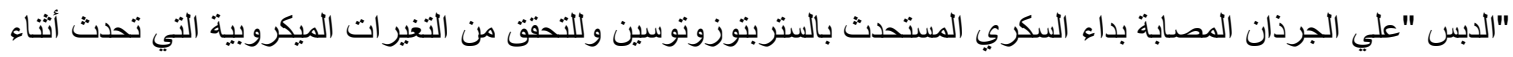

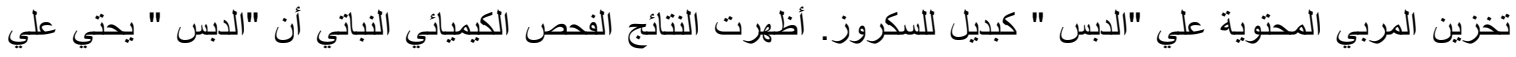

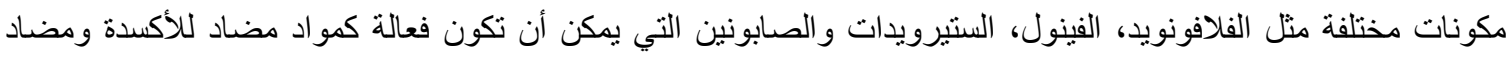

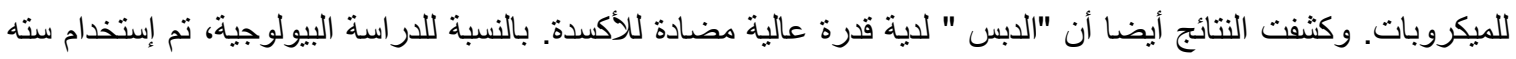

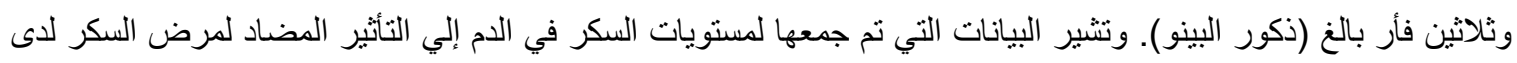

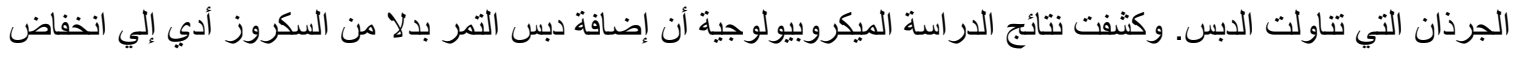

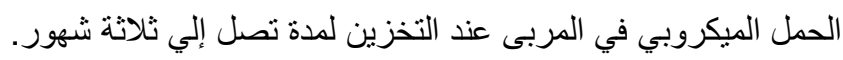
الكلمات الدالة : دبس التمر -ستربتوزوتوسين - عرض السكرى ـ مكونات فيتوكيميائية ـ مضادات أكسدة - مضادات بكتريا 